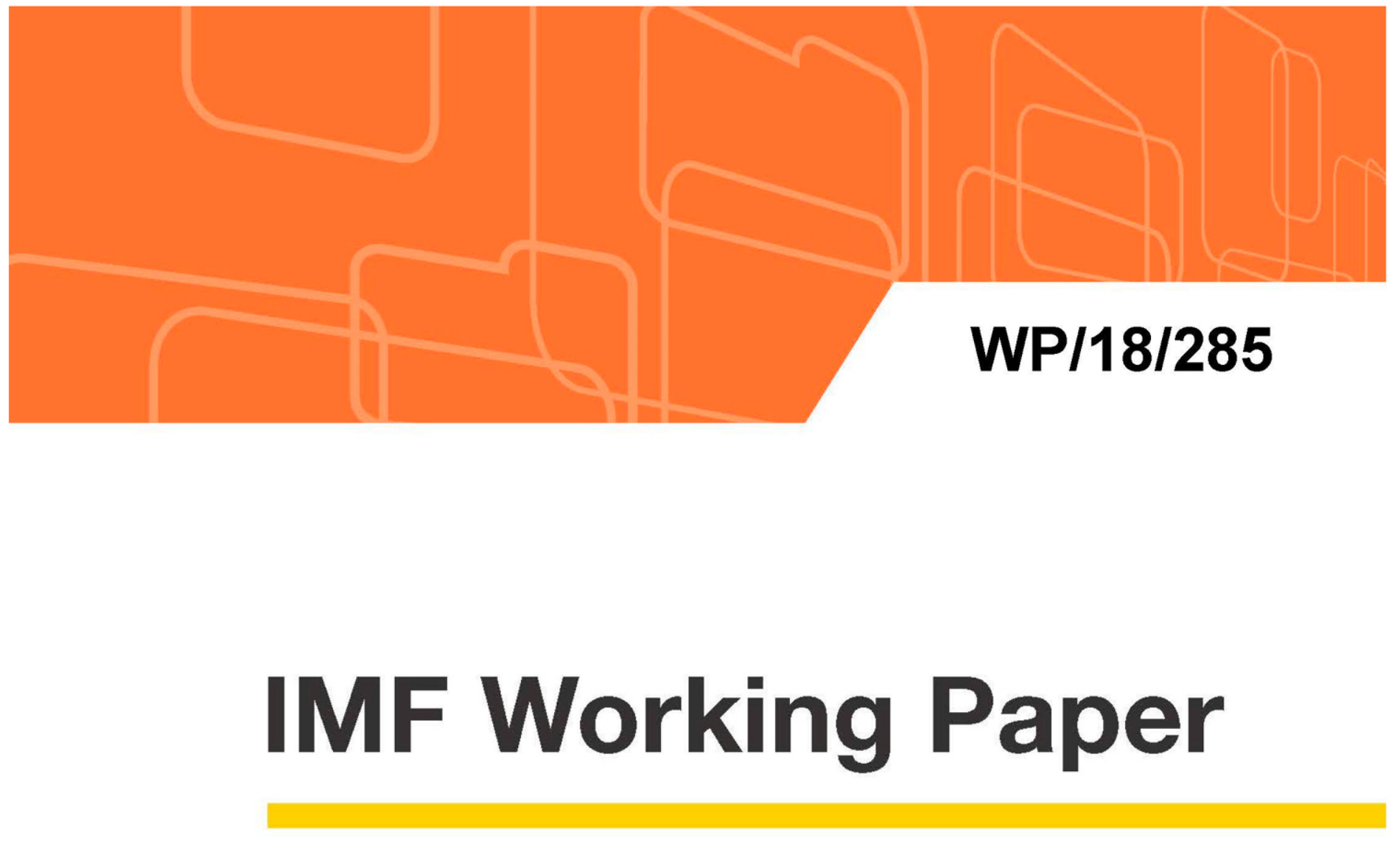

\title{
Assessing the Macroeconomic Impact of Structural Reforms in Chile
}

by Metodij Hadzi-Vaskov

IMF Working Papers describe research in progress by the author(s) and are published to elicit comments and to encourage debate. The views expressed in IMF Working Papers are those of the author(s) and do not necessarily represent the views of the IMF, its Executive Board, or IMF management.

$$
\text { I N T E R N A T I O N A L M O N E T A R Y F U N D }
$$




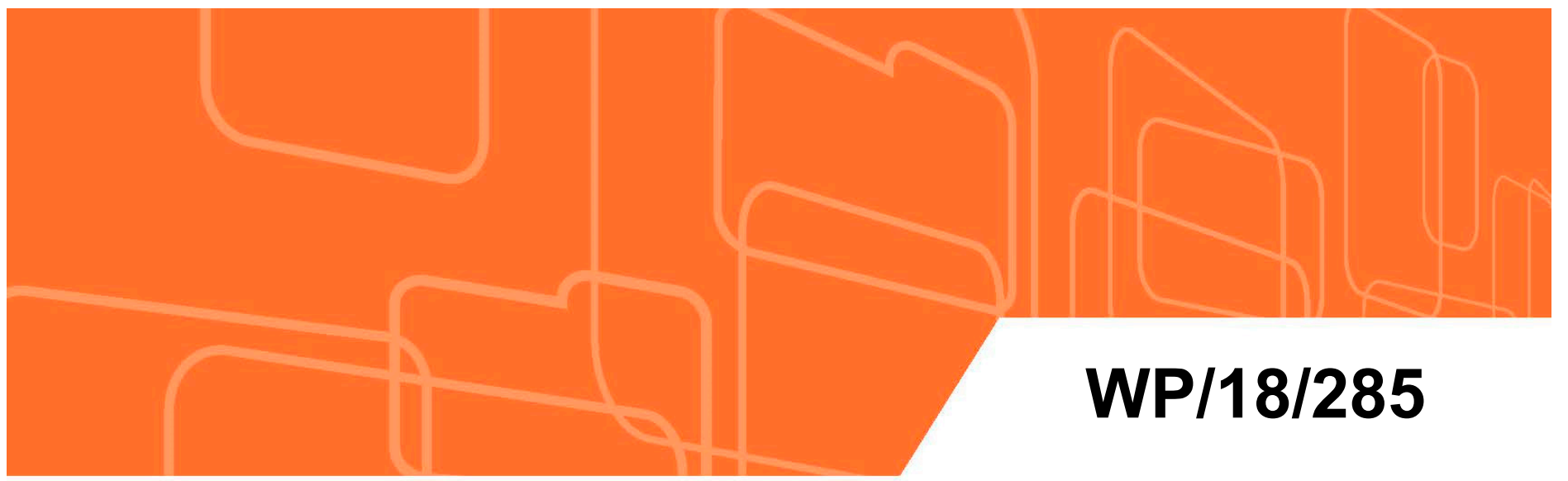

\section{IMF Working Paper}

\section{Assessing the Macroeconomic Impact of Structural Reforms in Chile}

by Metodij Hadzi-Vaskov

IMF Working Papers describe research in progress by the author(s) and are published to elicit comments and to encourage debate. The views expressed in IMF Working Papers are those of the author(s) and do not necessarily represent the views of the IMF, its Executive Board, or IMF management.

$$
\text { I N TER N A T | O N A L M O N E T A R Y F U N D }
$$




\title{
IMF Working Paper
}

Western Hemisphere Department

\section{Assessing the Macroeconomic Impact of Structural Reforms in Chile Prepared by Metodij Hadzi-Vaskov}

\author{
Authorized for distribution by Luca Antonio Ricci
}

December 2018

\section{IMF Working Papers describe research in progress by the author(s) and are published to elicit comments and to encourage debate. The views expressed in IMF Working Papers are those of the author(s) and do not necessarily represent the views of the IMF, its Executive Board, or IMF management.}

\begin{abstract}
This study investigates the likely macroeconomic impact of various structural reforms that align the Chilean regulatory framework with international best practices. In this context, the analysis: i) presents a comparison across a large set of structural indicators; ii) identifies policy gaps with respect to OECD countries; and iii) provides quantification of the likely growth and fiscal impact of policy reforms needed to close the gaps. Chile's economy is likely to benefit from streamlining business regulation and licensing, strengthening innovation and R\&D capacity, improving labor market flexibility, and enhancing active labor market policies. Overall, the study presents a scenario in which Chile closes structural gaps with OECD's $25^{\text {th }}$ percentile over five years, with up to 6 percent higher output level and a cumulative net fiscal gain of about $1 / 2$ percent of GDP.
\end{abstract}

JEL Classification Numbers: L51, O47, O54

Keywords: Structural Reforms, Chile, Productivity

Author's E-Mail Address: MHadziVaskov@,imf.org 


\section{INTRODUCTION ${ }^{1}$}

This study aims to investigate alternative portfolios of structural reforms in Chile and their likely macroeconomic effects. Chile's transition toward an advanced-economy status critically depends on implementation of a comprehensive set of structural reforms that can align the regulatory framework with international best practices. In this context, the analysis follows an eclectic approach, starting from an international comparison across a large set of indicators, via the identification of policy gaps with respect to OECD countries, to a quantification of the growth and fiscal impact of closing such policy gaps.

The focus areas of this study correspond to the types of structural reforms that are found to have the highest potential for productivity payoffs in emerging markets and advanced economies. Figure 1 summarizes the likely impact (based on IMF research) of various structural reforms on productivity, conditional on the countries' income level. ${ }^{2}$ It suggests that product market and labor market regulations should be priority reform areas for emerging markets, while innovation and technology also join the set of priorities for advanced economies. In addition, education and training reforms are likely to provide general impulse that is essential for the success of various reforms across the policy spectrum.

Figure 1: Structural Reforms with the Highest Productivity Payoffs

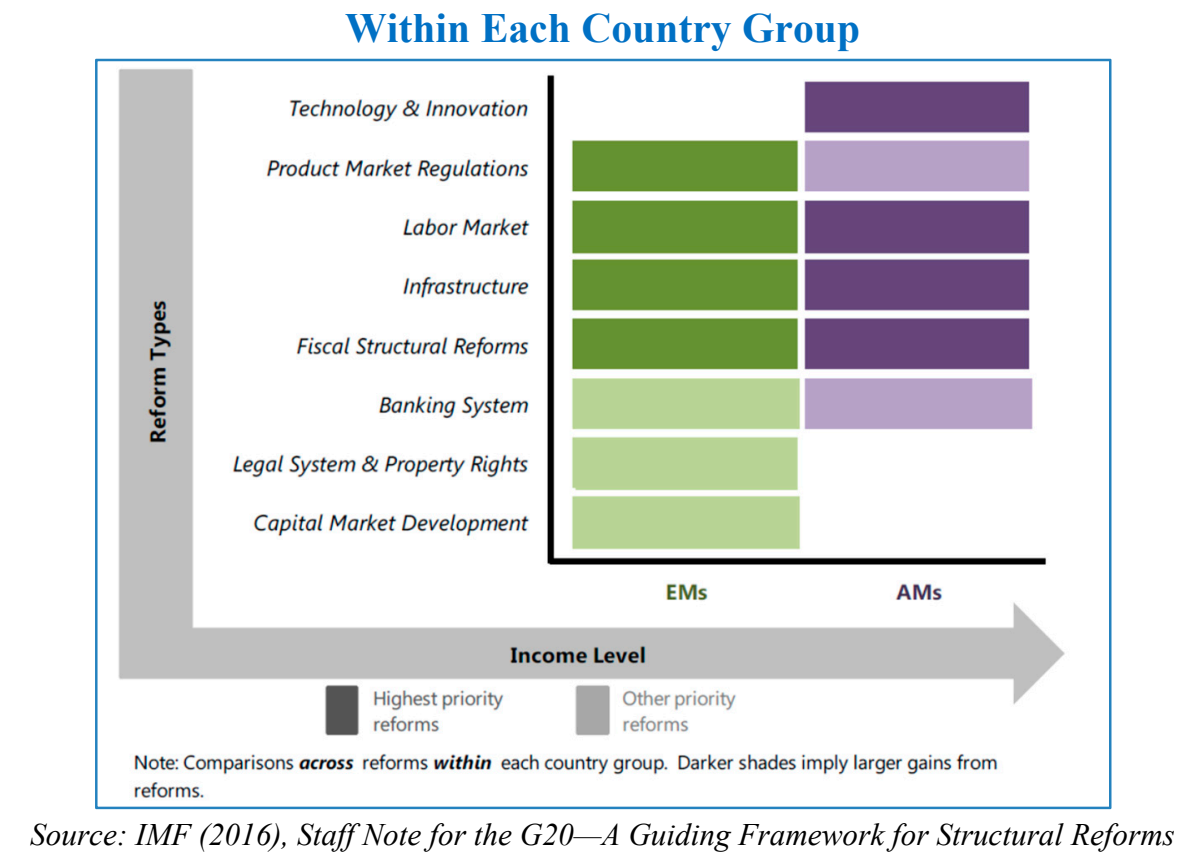

\footnotetext{
${ }^{1}$ The author is grateful to Luca Antonio Ricci for overall guidance and support, and to Romain Duval for helpful discussions and suggestions.

${ }^{2}$ See IMF (2015) for an overview of findings in this area.
} 
The rest of this paper is organized as follows. Section II sets the stage by comparing Chile with Latin America and OECD countries across a broad set of structural indicators. Section III describes the policy gaps with a view to identifying the structural reforms that have potentially the largest pay-offs in terms of increasing output. Section IV provides a quantification of the output and fiscal impacts of various policy measures and Section $\mathrm{V}$ presents a similar analysis about alternative reform scenarios. Section VI draws on historical evidence about synchronicity and possible complementarity of structural reforms. Finally, Section VII contains some concluding remarks.

\section{COMPARISON OF STRUCTURAL INDICATORS: CHILE, LATIN AMERICA AND OECD}

Using an extensive dataset of structural indicators, this section follows a descriptive approach to illustrate Chile's standing relative to the group of Latin American peers and the OECD members. Data series come from the following widely available sources: World Bank's World Development Indicators, Ease of Doing Business, and Education Statistics; World Economic Forum's Global Competitiveness Indicator; and International Labor Organization's Employment Protection Legislation Database. All indicators are adjusted in the figures presented below, so that higher values always imply better outcomes.

Chile stands favorably in international comparisons in several areas relevant for economic performance and productivity improvements (see Figure 2). Such areas include connectivity (measured for example by mobile phone subscriptions), enrollment in tertiary education, and adult literacy. In these areas Chile is not only at the top in Latin America, but also among the best performers in OECD. Similarly, faster access to electricity connection, more competitive labor taxes, and higher level of financial inclusion (measured by share of firms with checking or savings accounts) stand high relative to most Latin American and OECD countries, and provide a positive contribution to Chile's overall business environment.

With respect to other structural indicators, Chile typically outperforms countries in Latin America, but lags behind OECD countries. The rest of the paper focuses on a comparison of four key areas that appear as relatively weak by international standards, andat the same time - are commonly identified in the literature as essential for strengthening productivity prospects and enhancing economic growth: product market regulation and competition; labor market policies; innovation capacity and R\&D; and education and training. The comparison is followed by a quantification of the effects of the policy reforms in these four areas. 


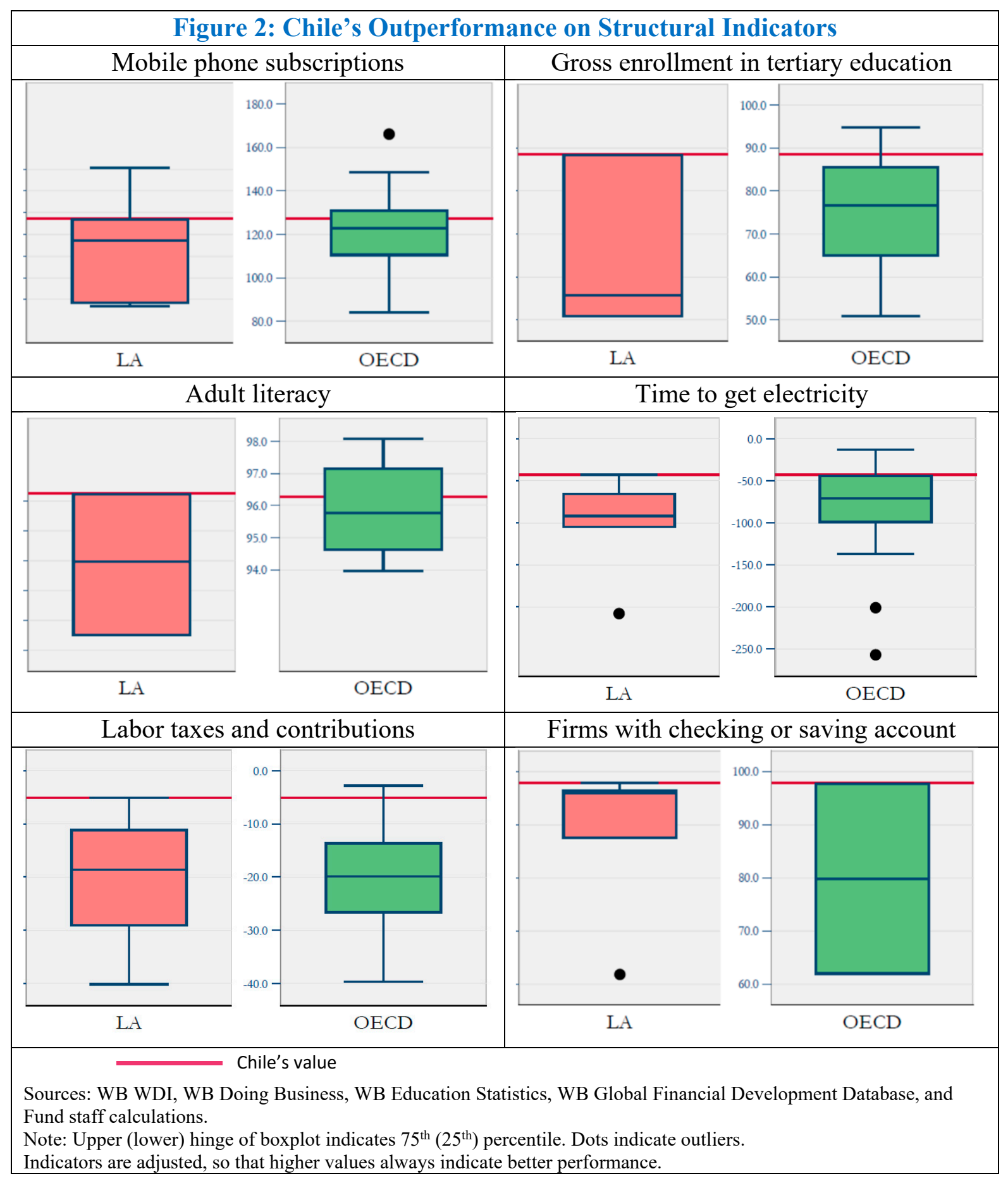




\section{A. Product market and competition}

Market concentration is perceived to be worse than both other countries in the region and the OECD. Large companies seem to dominate several domestic market segments (WEF, 2017), suggesting possible impairment of competition in the domestic market and potential obstacles to market entry. However, anti-monopoly policy is perceived as more effective than in other countries in the region and quite in line with many OECD countries, suggesting that such policy is neither the culprit of the strong market concentration nor an adequate tool to tackle it (such as in maritime transport).

\section{Infrastructure quality and internet penetration are higher than in regional peers.} Quality of road, railway, and air transport infrastructure is at the top of Latin America, but considerably below OECD countries. Similar picture (relative standing) emerges when looking at internet penetration, measured by broadband subscriptions, internet users, or internet access in schools, which suggests that Chile may have relatively better potential for adopting new IT-based productivity enhancements.

\section{More procedures are needed to start business or register property than in three} quarters of OECD countries. While indicators suggest that Chile fares relatively well in the regional context, there seems to be ample scope to streamline some regulations. Cumbersome procedures put a burden on business activity and negatively affect Chile's competitiveness. 


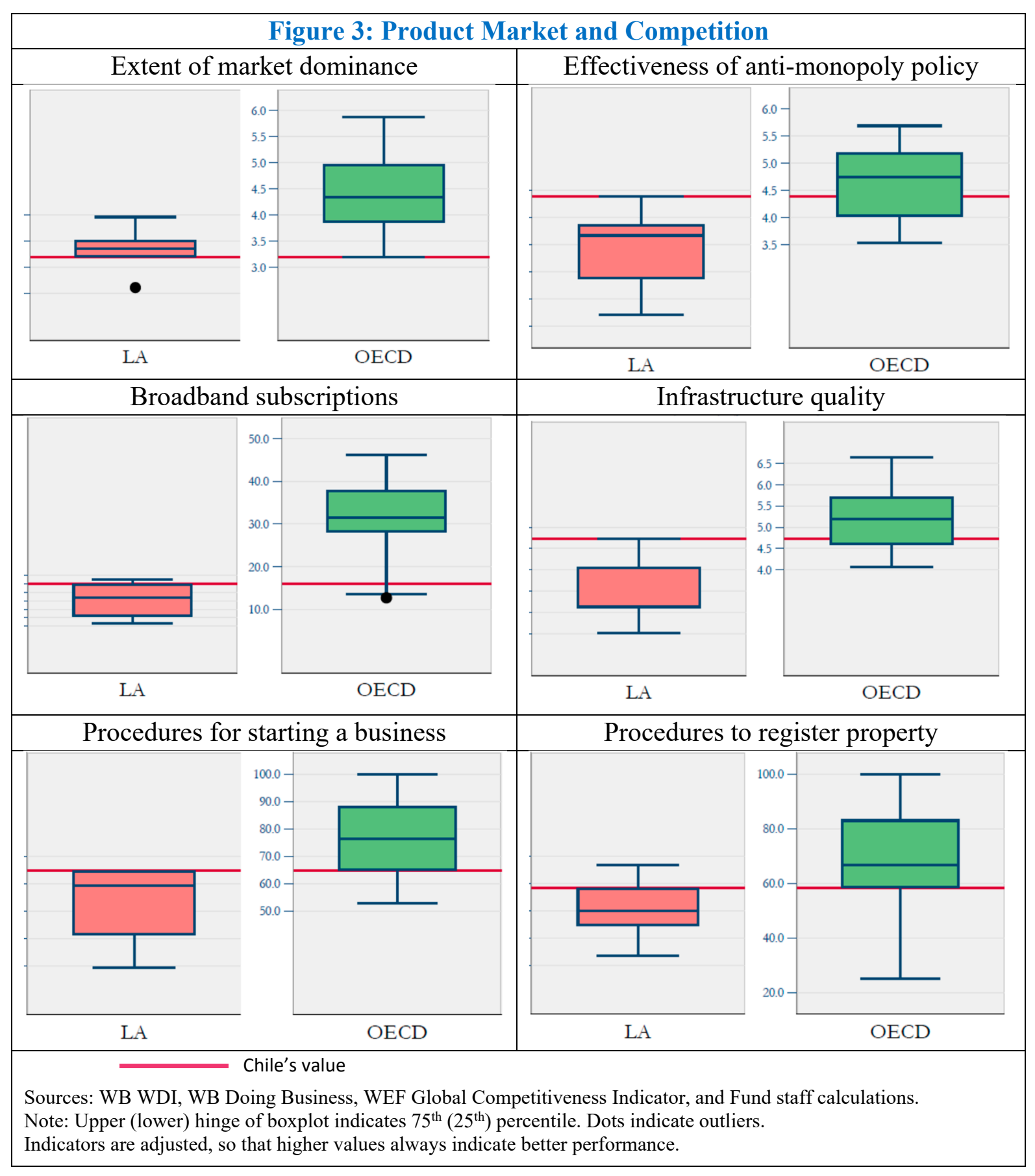




\section{B. Labor market}

There is room to enhance labor market efficiency. Redundancy costs are higher in Chile than most countries in both Latin America and OECD. Similarly, hiring and firing legislation provides considerably less flexibility than most OECD members and close to half of Latin American peers. There is ample room to increase female labor force participation, which is at the median of LA countries and among the lowest levels of OECD countries. Employee training, an important factor for improving skill-matches and labor market efficiency, compares favorably with the region, but lags behind OECD. This is most likely due to relatively inefficient allocation of resources for employee training in Chile.

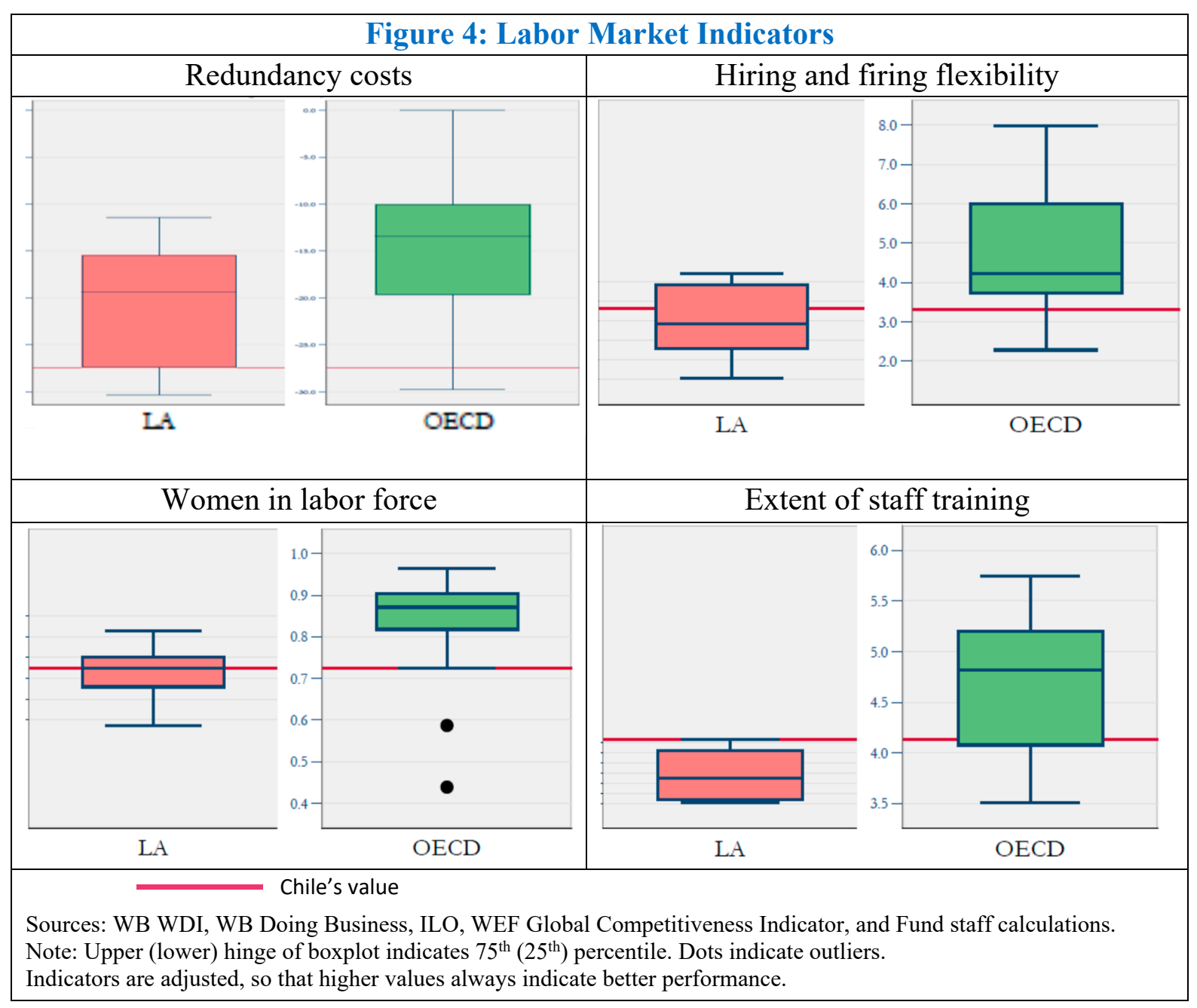




\section{Innovation and R\&D}

Registered R\&D spending by Chilean companies and capacity for innovation are actually lower than or at Latin America's median, as well as at the bottom among OECD members. On other indicators in this area, such as industry-university collaboration and innovation and sophistication factors, Chile fares better than Latin American peers, but still considerably below most OECD countries.

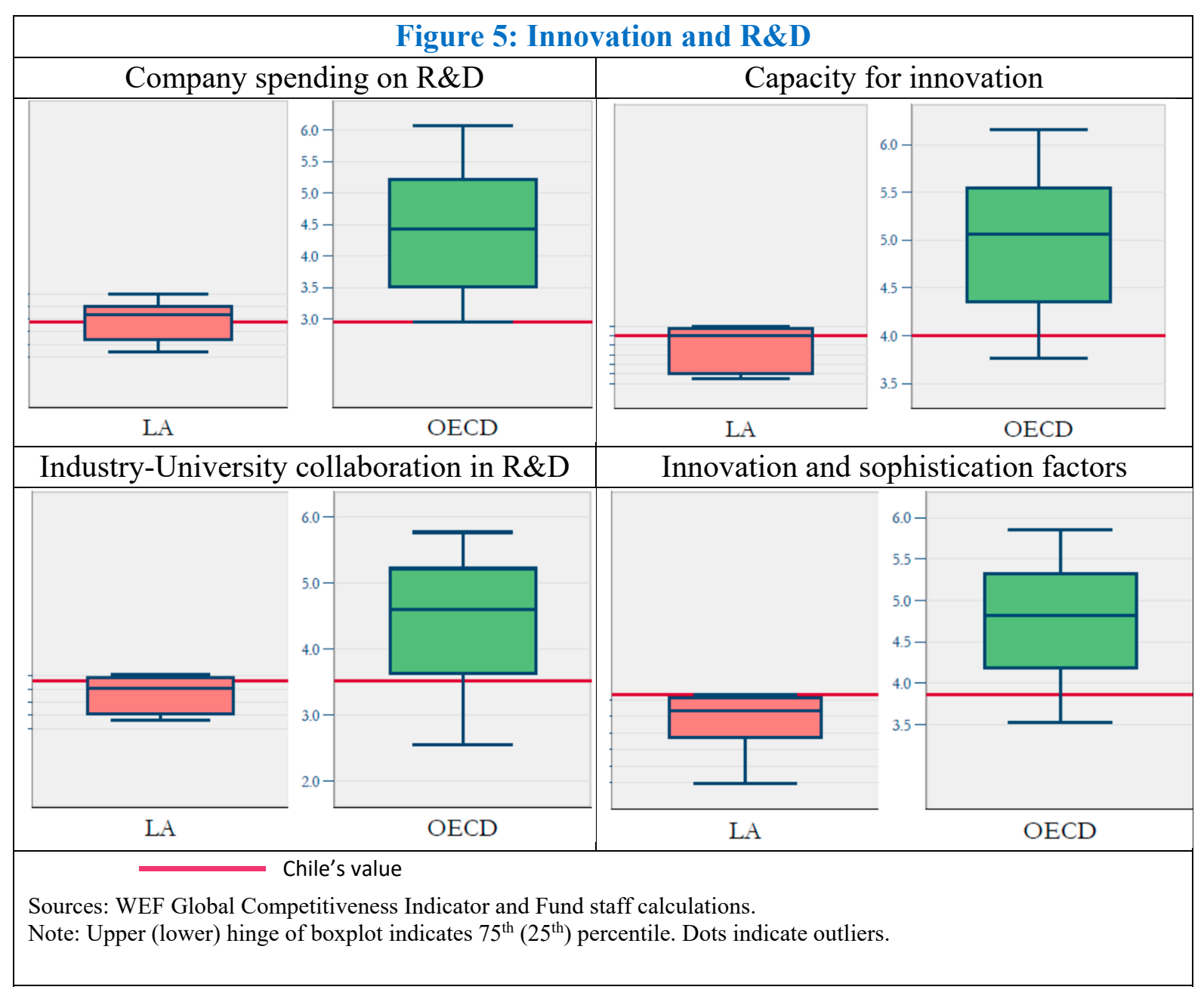




\section{Education}

Education indicators suggest substantial underperformance relative to OECD, although generally are better than regional peers. Although overall government spending on education (share of GDP) is at the top in Latin America, expenditure per tertiary student (measured as share of GDP per capita) seems to be among the lowest in the region (this is expected to change with the recent education reform). Importantly, the share of engineering in total graduates, crucial factor for adoption of new technology and innovation, seems to be at the very bottom in Latin America. Student assessment scores, measured by OECD's PISA, suggest that education quality is better than regional peers, but below most OECD countries.

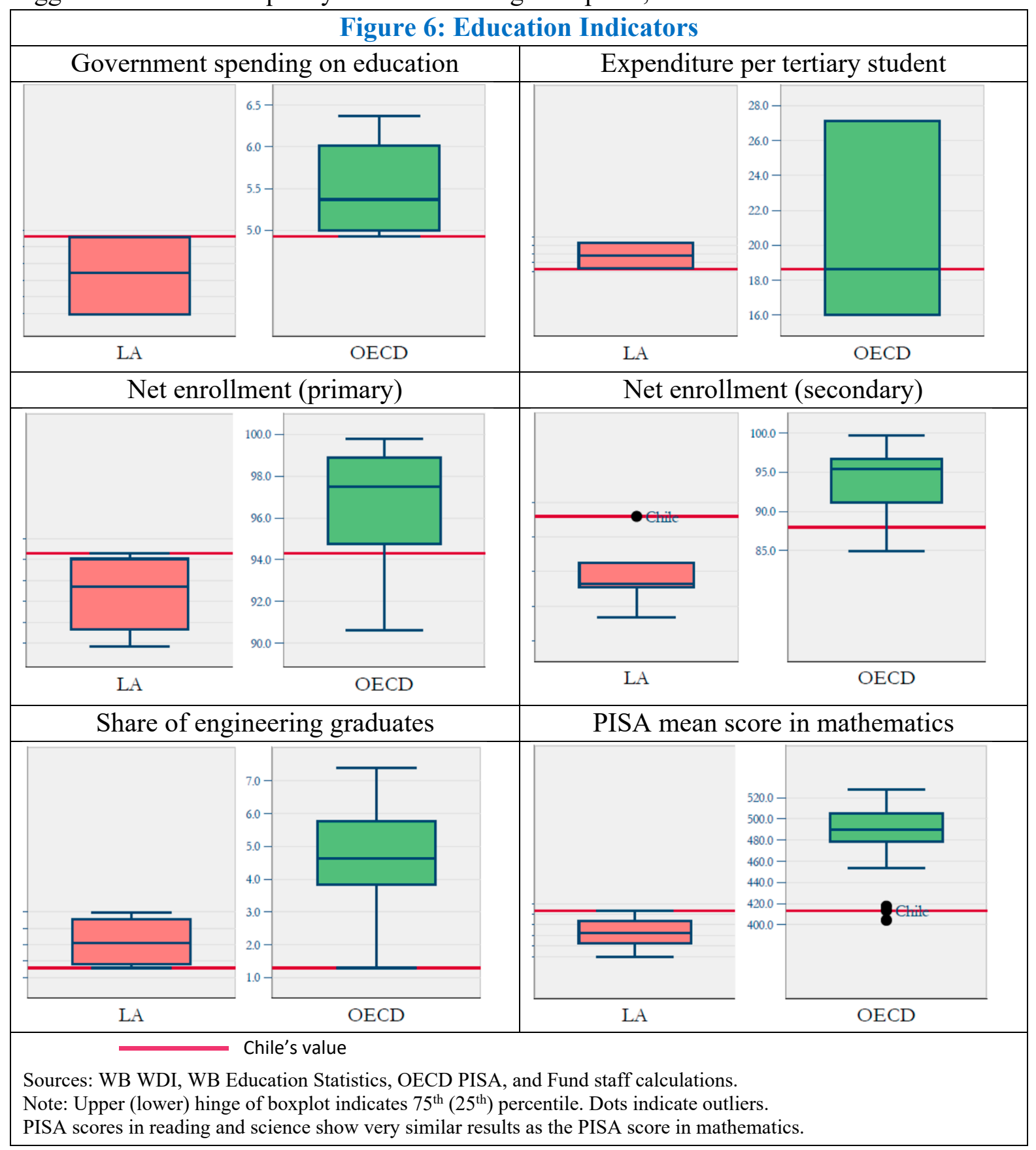




\section{IDENTIFICATION OF POLICY GAPS}

This section aims at identifying measures of policy gaps relative to OECD peers that can not only be assessed in a comparable manner, but also whose macroeconomic effects have been empirically quantified in a consistent manner. For this purpose, the analysis uses indicators from OECD's Structural Policy Indicators Database for Economic Research (SPIDER) that allow for consistent comparisons across all OECD member countries. This database compiles series from various sources. Among others, it includes sets of OECD indicators on: regulation in energy, transport and communications (ETCR); product market regulation (PMR); employment protection legislation (EPL); and innovation and R\&D spending (OECD Main Science and Technology Indicators). Table 1 summarizes these indicators and their scale/measurement units.

\begin{tabular}{|l|l|}
\hline \multicolumn{2}{|c|}{ Table 1: Overview of Structural Indicators } \\
\hline Structural indicator & Scale/Measurement \\
\hline ETCR Aggregate & Index, 0-6, 6 strictest \\
\hline ETCR Entry barriers & Index, 0-6, 6 strictest \\
\hline ETCR Public ownership & Index, 0-6, 6 strictest \\
\hline PMR Licenses and permits system & Index, 0-6, 6 strictest \\
\hline Expenditure on R\&D & Percent of GDP \\
\hline Employment protection legislation & Index for regular contracts, 0-6, 6 strictest \\
\hline Unemployment benefit replacement rate & Percent of wages earned when employed \\
\hline ALMP spending on unemployed & Percent of GDP per capita \\
\hline Minimum wage & Percent of median wage \\
\hline Family benefits in kind & Percent of GDP \\
\hline Legal retirement age & Legal age for pensions \\
\hline Source: OECD's Structural Policy Indicators Database for Economic Research (SPIDER) \\
\hline
\end{tabular}

Figure 7 provides an overview of identified policy gaps with respect to the OECD group. Chile's position is marked by a red diamond, the position of OECD's top performer by a black diamond, and the bars correspond to the $25^{\text {th }}$ to $50^{\text {th }}$ percentile range of OECD distribution (lighter) and $50^{\text {th }}$ to $75^{\text {th }}$ percentile range of OECD distribution (darker). When necessary, the sign of policy indicators is adjusted, so that in all cases upper values correspond to regulations/policies that are found to be more conducive to productivity and growth. Such adjustments are applied to the following indicators: business licensing and regulation; regulation in energy, transport, and communications; employment protection legislation; and minimum wage (as percent of median wage).

The potential to improve economic performance is especially large in business licensing and regulations. Chilean businesses seem to be considerably more burdened by license and permit regulation than all other OECD countries. In fact, an improvement to the level of OECD's $25^{\text {th }}$ percentile is likely to require significant streamlining of business licensing with 
potentially large benefits. On the other hand, potential benefits from regulatory reforms in key network industries, such as energy, transport, and communications, seem limited, as the country appears aligned with the OECD median.

Chile can also reap economic benefits by closing the policy gaps in labor market issues and innovation. Employment protection legislation seems to act as a constraint to job creation and economic activity, particularly due to high severance payments and lengthy dismissal procedures. Further focus is needed on strengthening active labor market policies (ALMP), where overall spending in Chile (as percent of GDP per capita) is significantly lower than most OECD countries. Similarly, an adjustment of the minimum wage, which may be binding especially for SMEs, could make the labor market more flexible. At the same time, to the extent the minimum wage policy plays a useful role in ameliorating working poverty, such adjustments will need to be accompanied by a targeted expansion of the social safety net to offset the possible adverse effects on poverty. Policy gaps in family benefits in kind (childcare) and retirement age are considerably smaller, and the current plan to provide universal childcare access (sala cuna) may further strengthen Chile's position. Finally, reported figures suggest that Chile has persistently underspent on R\&D relative to OECD peers, with most of R\&D and innovation spending coming from the public funds, while contributions from the private sector have been very limited.

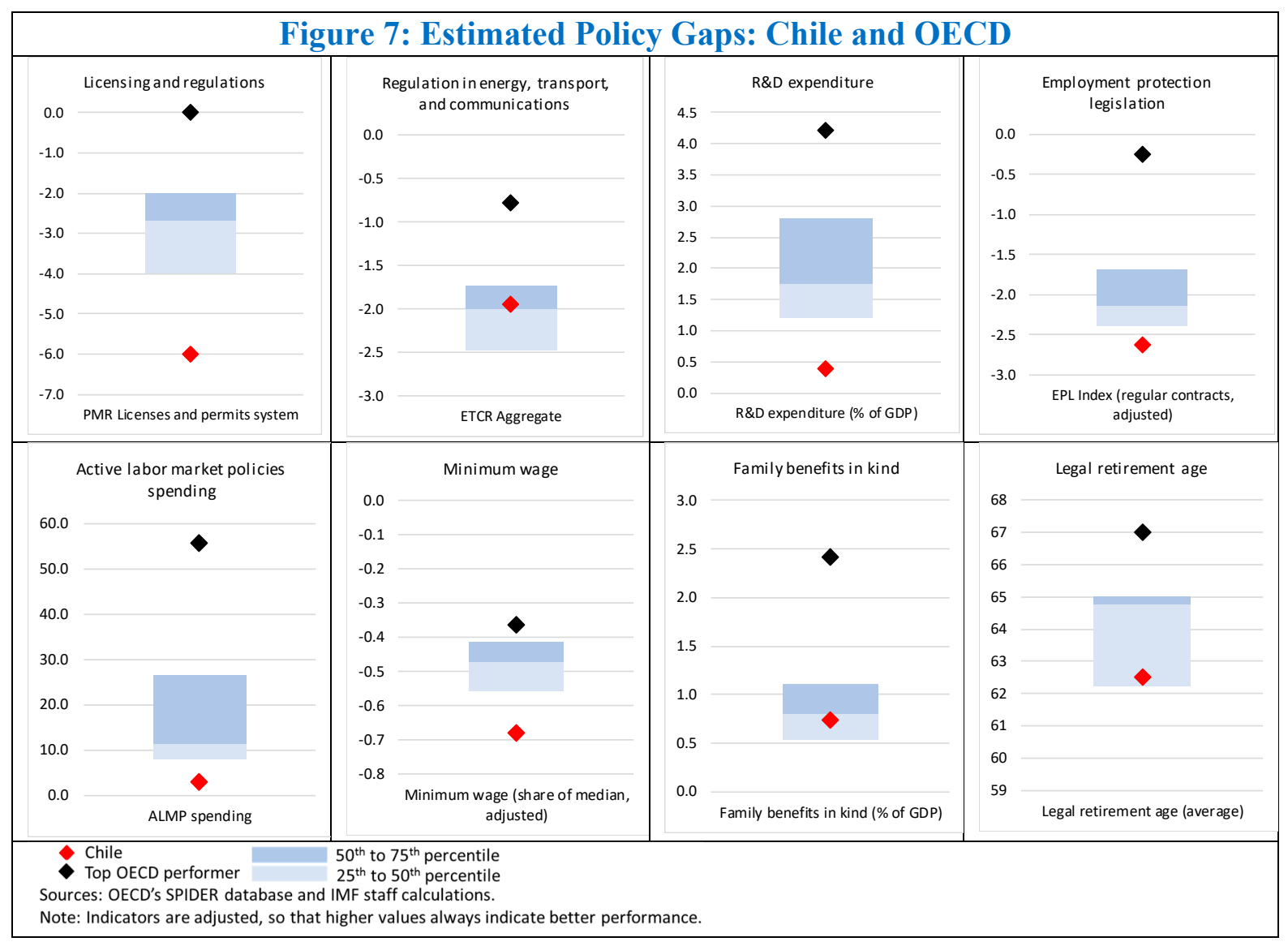




\section{QUANTIFYING GROWTH AND FISCAL IMPACT OF POLICY MEASURES}

\section{The impact of structural reforms is quantified on the basis of both identified policy} gaps and estimated policy effects with respect to key indicators. The baseline scenario in this analysis presents results for closing Chile's policy gaps to the level of OECD's $25^{\text {th }}$ percentile. ${ }^{3}$ Formally, the policy gap is identified by $\left(S_{i}-S_{i}^{*}\right)$, where $S_{i}$ stands for Chile's value of the structural indicator in reform area $i$, and $S_{i}^{*}$ is the value of this indicator that corresponds to the $25^{\text {th }}$ percentile of the $\operatorname{OECD}\left(S_{i}\right.$ and $S_{i}^{*}$ are visible in Figure 7$)$. With respect to the effect of individual policies on output, this study relies on typical estimates found in the literature, those presented in Égert and Gal $(2016,2017)$ and OECD (2018). More precisely, the marginal impact on output of each structural policy change $\partial Y / \partial S_{i}$ is calculated on the basis of the estimates in Égert and Gal $(2016,2017)$ about the average output effect of typically observed structural policy reforms over a 5 -year period. ${ }^{4}$ Overall, the output impact of reform $i$ denoted as $R I_{i}$ is calculated as the product of the policy gap and the estimated output effect of a unit change in the corresponding policy indicator:

$$
R I_{i}=\frac{\partial Y}{\partial S_{i}}\left(S_{i}-S_{i}^{*}\right)
$$

It is well known that there is considerable uncertainty about the output effects of structural reforms, which can be related to measurement problems, empirical specifications employed, and possible omitted variables. Hence, the quantitative results in this paper should be taken cautiously and may overestimate the true effect of reforms. The quantitative analysis focuses on the indicators with the largest policy gaps identified in Figure 7: business licensing and regulation; R\&D expenditure; active labor market policies; and employment protection legislation and minimum wage (the last two grouped together as labor market regulations). ${ }^{5}$ The results for this scenario are presented in Figure 8.

\footnotetext{
${ }^{3}$ A more ambitious scenario presented in the next section shows the results for a case in which policy gaps are closed to the level of OECD median for each indicator.

${ }^{4}$ Typically observed reforms here refers to the average of all beneficial two-year policy changes observed over two consecutive years in the sample in Égert and Gal $(2016,2017)$.

${ }^{5}$ Future work should focus on broadening the set of structural indicators for which comparable and consistent estimates are available.
} 
Figure 8: Impact of Structural Reforms on GDP Level

(Reach $25^{\text {th }}$ Percentile of OECD, in Percent)

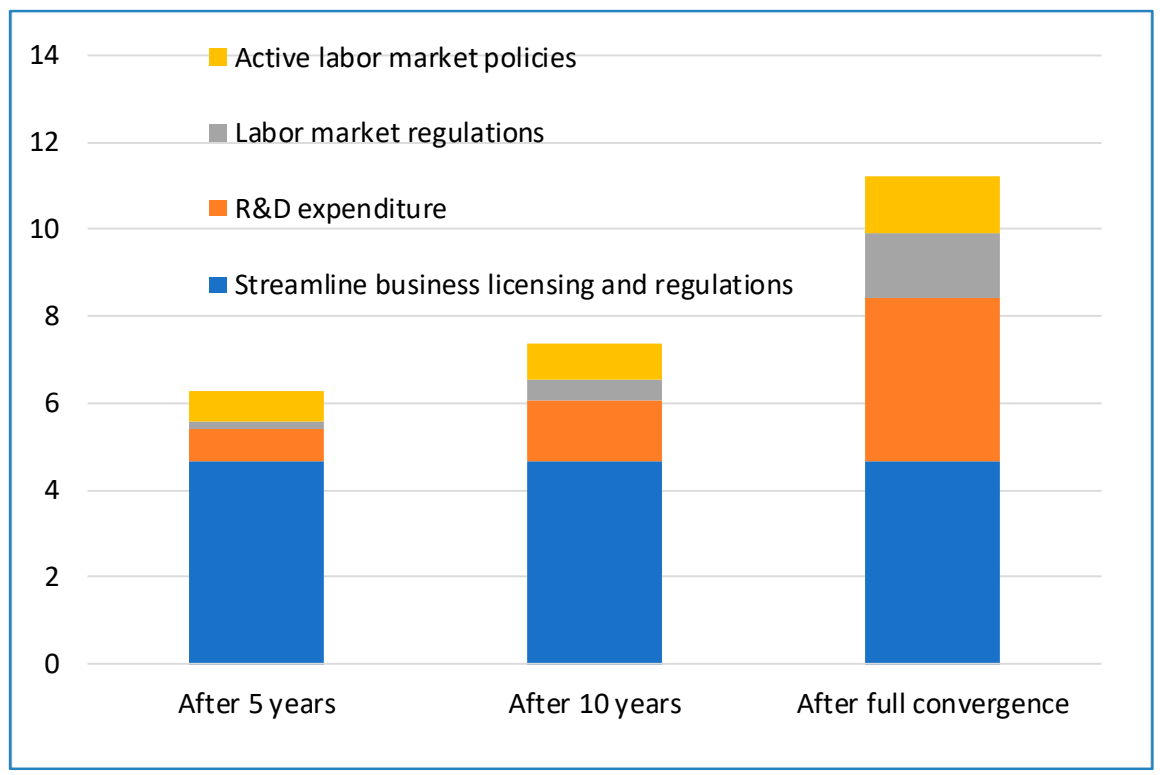

Source: IMF staff calculations based on Égert and Gal (2016, 2017) and OECD (2018).

The quantification of structural reforms corresponds to a concrete set of structural measures. Improvements in business licensing and permits accounts for the largest impact on output level, reflecting the significant policy gap identified in Figure 7 and the important output effect of unit change in these indicators, as implied by Égert and Gal $(2016,2017)$. Moreover, the output dividends resulting from this policy action materialize mainly over the first 5 years in this setup. Note that Duval and Furceri (2018) show that such gains are likely to be backloaded, possibly towards the end of the 5-year horizon. When it comes to higher R\&D and innovation expenditure the effects on output are likely to need even more time to fully materialize (over 10 years), in line with the general expectation about time lags in innovation and R\&D. Similarly, the impact of higher labor market flexibility, and to a lesser extent, of enhanced ALMPs, takes several years.

Policy actions, that would help close the policy gaps, are described in Box 1. These areas broadly correspond to those underlined in OECD (2018) and the priorities emphasized by business sector representatives. 
Box 1: Structural measures to close gaps with OECD's $25^{\text {th }}$ percentile

Streamline business licensing to help move Chile from score 6 to score 4 on PMR licenses and permits system indicator:

- Reform and simplify procedures for business licenses and permits, and lower permit status uncertainty.

- Improve coordination among different license-issuing institutions (central government, municipalities, sectoral authorities), possibly by introducing a single point (single window) for business procedures and licenses.

- Reduce involvement of notaries in many procedures to shorten time lags and lower business costs.

- Strengthen the "a silence is consent" principle for administrative procedures by tackling challenges in its current application (reduce perceived stigma by regulator to encourage economic agents to use it; reduce chances of procedural limbos).

- Fully implement in practice the law for starting a business in one day.

Enhance active labor market policies (ALMP):

- Increase spending per unemployed worker from current equivalent of 3 percent of GDP per capita to 8 percent of GDP per capita (amounting to a cumulative increase in spending of about 0.5 percent of GDP over 5 years) and make them strictly conditional on following training courses and active search for job opportunities (level of 25th percentile in the OECD); ensure funding through redirection of funds due to improved targeting and eligibility controls.

- Enhance targeting towards unemployed workers, who face serious hurdles to access adequate re-training programs.

- Strengthen evaluation of ALMPs effectiveness, enhance selection and certification. Increase spending on innovation and R\&D from current 0.4 percent of GDP to 1.2 percent of GDP in line with the $25^{\text {th }}$ percentile in the OECD:

- Focus on providing incentives to businesses through tax credits (application of current 35 percent deduction) and simplified certification procedures; aim to increase business R\&D expenditure from current 0.1 percent to 0.7 percent of GDP.

- Clarify eligibility for tax deductions in cases of acquisition of innovative companies.

- Improve recording of innovation and R\&D expenditure, particularly by private sector.

- Strengthen assessment of public policy effectiveness and focus on measures that yielded best results (such as successful projects at Fundación Chile).

Increase labor market flexibility to the level of OECD's $25^{\text {th }}$ percentile:

- Reduce severance costs and dismissal procedures to increase chances of jobs creation in the formal sector.

- Lower severance costs to align with 25 th percentile in OECD, which implies to about $1 / 2$ or less of the current level.

- Simplify dismissal procedure to lower legal uncertainty.

- Lower the eligibility threshold (of one year) for benefits coverage and allow proportional coverage of workers with precarious jobs.

- Adjust minimum wages to avoid binding constraints, particularly for SMEs. 


\section{Policy actions for specific demographic groups are likely to be relevant in more} ambitious reform scenarios. For instance, an increase of family benefits in kind, such as childcare spending, to the level of the OECD median (increase of about 0.1 percent of GDP) is estimated to result in 0.1 percent higher output over 5 years. In addition, an alignment of the legal retirement age for male and female to 65 has been estimated to result in 0.4 percent higher output level over 5 years (see Égert and Gal, 2017). However, in the case of Chile, the effect on output is likely to be more limited given that a large share of female employees continues to work after the legal minimum age of 60 because they do not receive all pension benefits before the age of 65 .

\section{The set of structural measures is likely to result in net fiscal gains over 5 years.}

Following an initial deterioration of the fiscal balance (down by close to 1 percent of GDP) due to direct costs of some policy measures (such as higher fiscal spending on ALMP, or larger public resources devoted to R\&D), the package of reforms is likely to pay for itself through higher output over the medium term, with net positive impact on the fiscal balance of about $1 / 2$ percent of GDP (see Figure 9). Estimates of the full fiscal impact is based on a unitary elasticity of revenues to output, which is consistent with the long-run elasticities estimated by Dudine and Jalles (2017).

Figure 9: Impact on Fiscal Balance

(Percent of GDP; Reach $25^{\text {th }}$ Percentile of OECD)

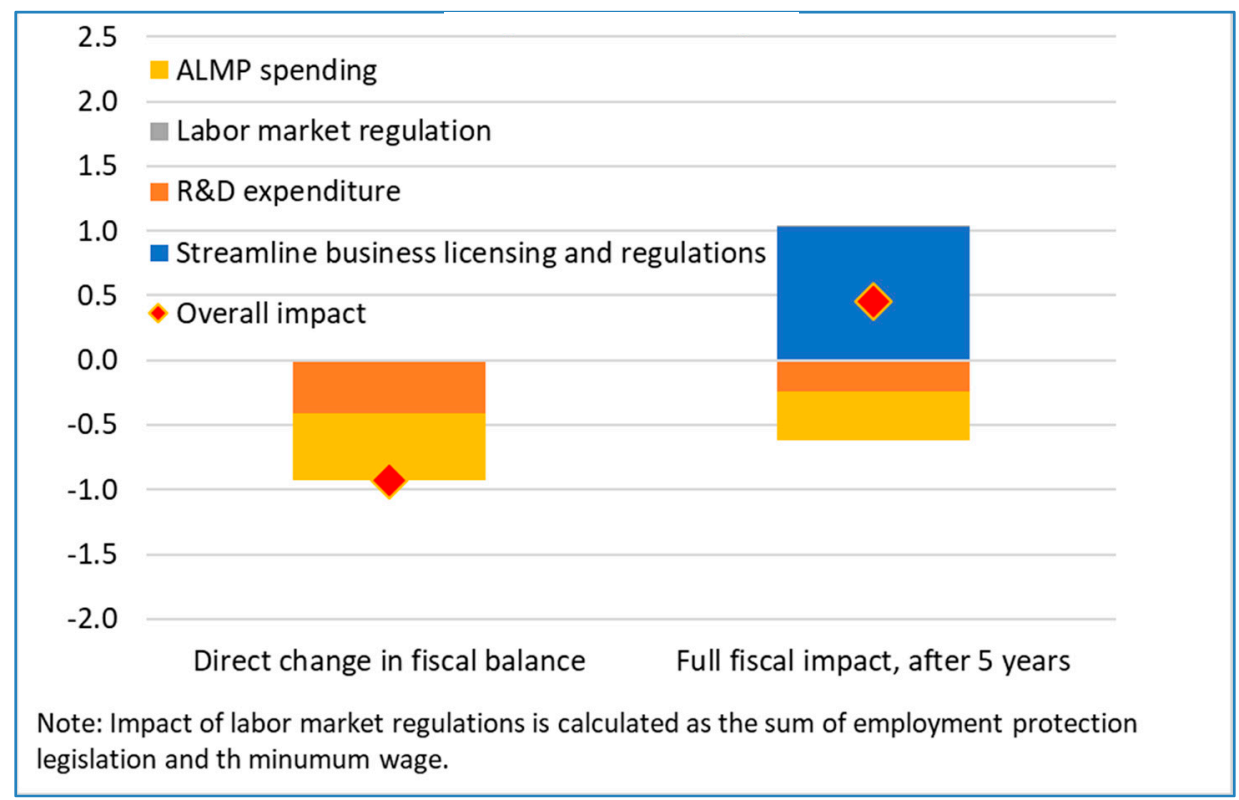

Source: IMF staff calculations based on OECD (2018).

The impact of structural reforms differs across factors of production. While streamlining business licensing and regulations plays a dominant role for all factors, the other reforms are concentrated on one factor. For instance, higher R\&D and innovation spending works fully 
through total factor productivity (TFP); enhanced labor market flexibility mainly contributes to faster capital accumulation; and the impact of ALMPs is shared between higher employment and TFP.

Figure 10: Impact on Factors of Production (TFP and $\mathrm{K} / \mathrm{L}$ in Percent, L/N in Percentage Points)

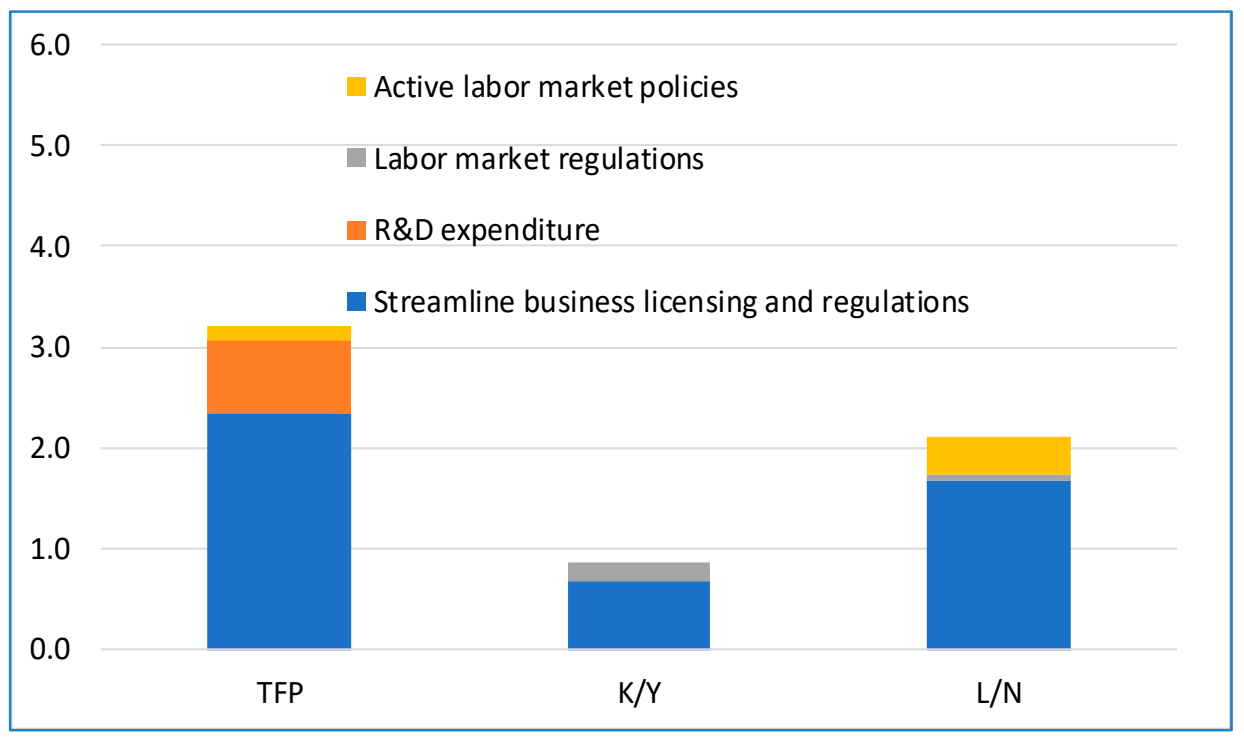

Source: IMF staff calculations based on Égert and Gal (2016, 2017) and OECD (2018). Note: TFP refers to total factor productivity, $L$ and $K$ to employment and capital stock, respectively, $N$ to labor force, and $Y$ to output.

\section{Improvements in education quality could have an over-arching impact by providing} key support to the success of various policy reforms quantified in this analysis. While education reforms are not the subject of our quantitative analysis in this paper (see OECD, 2017, 2018; World Bank, 2017), there are several areas with potentially high payoffs. For instance, focus on technical and engineering education with revamped curricula (programing skills, ICT, etc.) is essential to address skills shortages and help adoption of productivityenhancing technology and push forward the innovation agenda. Further integration of practical training in formal education curricula is likely to support labor market reforms. In this context, it is essential to further strengthen the assessment of education quality and open the possibility to explicitly link teachers' remuneration and/or school funding and management performance to student achievement scores. 


\section{Alternative Scenarios}

\section{A. Reform Scenario Based on International Experience}

Historical evidence suggests that the typical reforms implemented over the past four decades are considerably less ambitious than the baseline scenario envisaged in this paper (reaching the $25^{\text {th }}$ percentile of the OECD). This section presents a scenario comprised of the set of the typically-observed reforms in the entire SPIDER database over the past four decades. Such an exercise can offer an alternative to the baseline scenario, by presenting a set of reforms which are more likely to be implemented based on international experience. The typically-observed reforms are measured by the change of the corresponding structural indicator in each area over a 5-year period. The exercise then quantifies the likely impact of these reforms using the same framework as in the baseline scenario. Figure 11a suggests that the impact of such a scenario results in considerably lower output gains after 5 years (in the range of 1 1/2-2 percent) compared to the baseline scenario. ${ }^{6}$ Accordingly, the direct and indirect fiscal effects, as well as the impact of the factors of production, are much smaller than in the baseline. While such a reform scenario appears as less ambitious than the baseline and historical evidence indicates that each of its components materialized in many country cases, its feasibility depends also on the extent to which the envisaged reforms are likely to be implemented jointly_a topic explored further in Section VI.

Figure 11a: Impact of Structural Reforms on GDP Level (Typical set of reforms in OECD, in Percent)

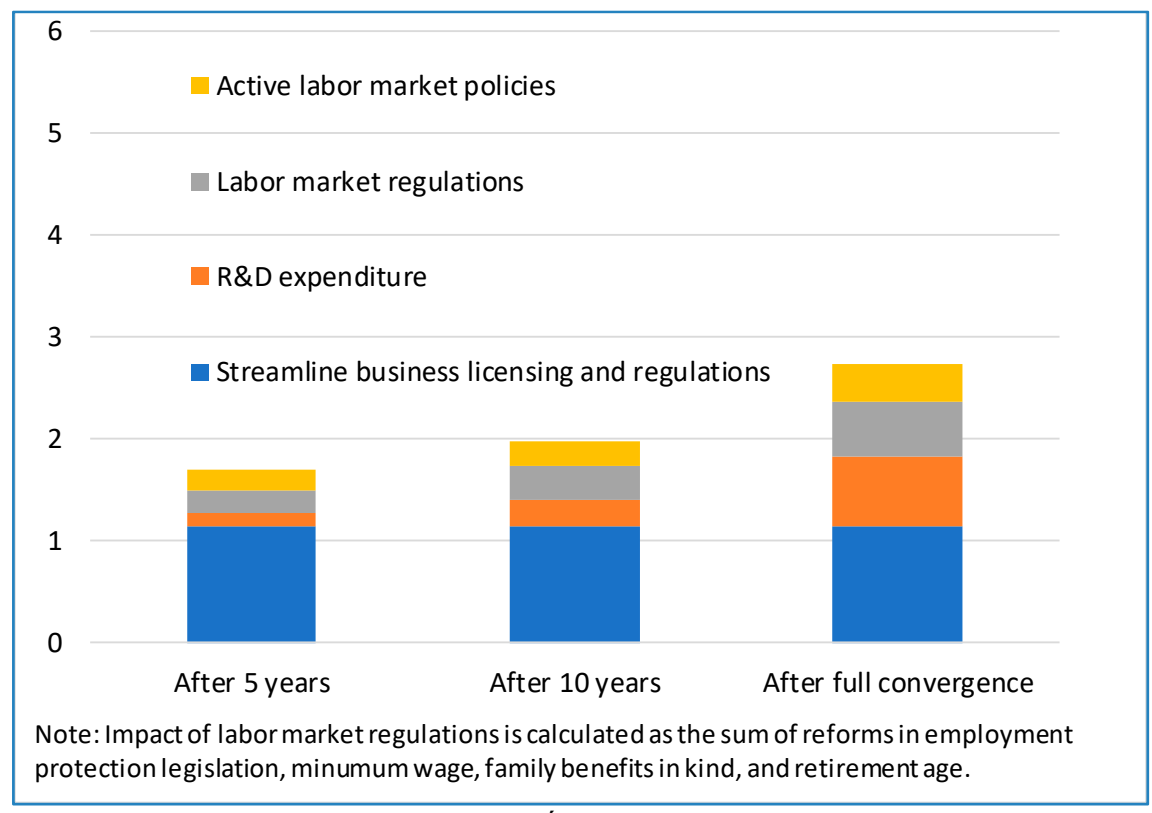

Source: IMF staff calculations based on Égert and Gal $(2016,2017)$ and OECD (2018).

\footnotetext{
${ }^{6}$ This typical scenario includes reforms in some areas in which Chile already ranks favorably to the $25^{\text {th }}$ percentile (or higher) of the OECD.
} 
Figure 11b: Impact on Fiscal Balance

(Typical set of reforms in OECD, in Percent of GDP)

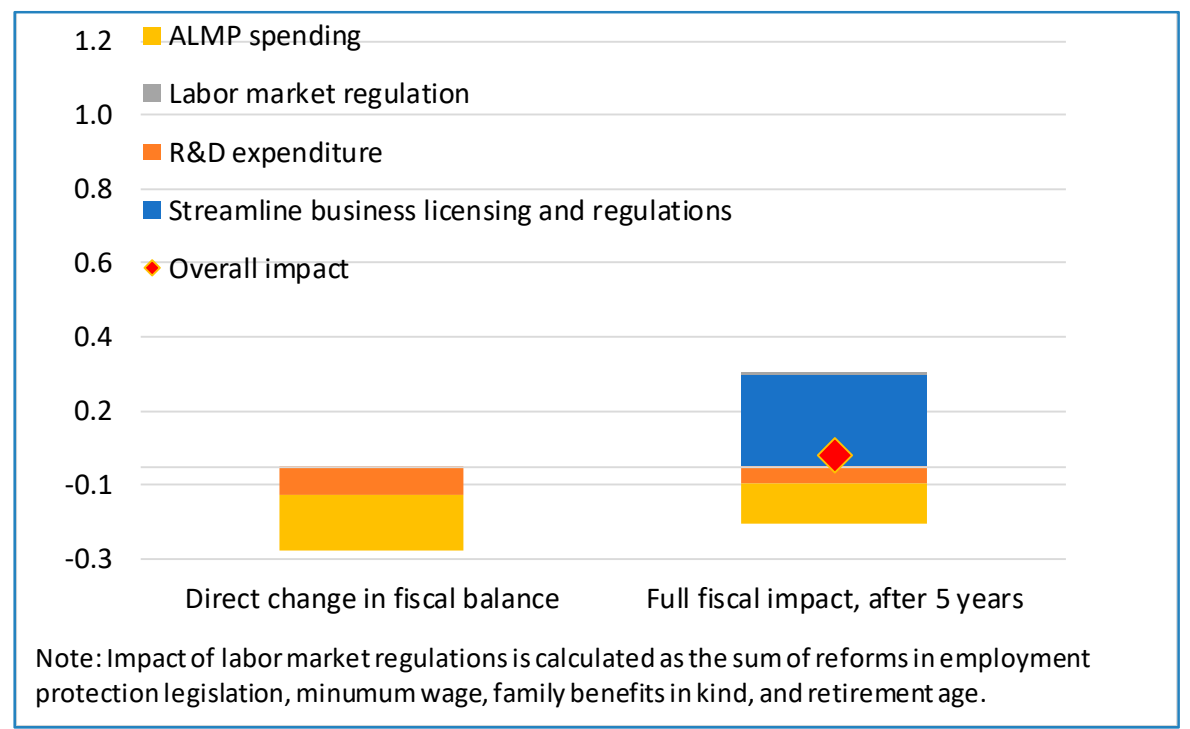

Source: IMF staff calculations based on OECD (2018).

Figure 11c: Impact on Factors of Production (TFP and $\mathrm{K} / \mathrm{L}$ in Percent, L/N in Percentage Points)

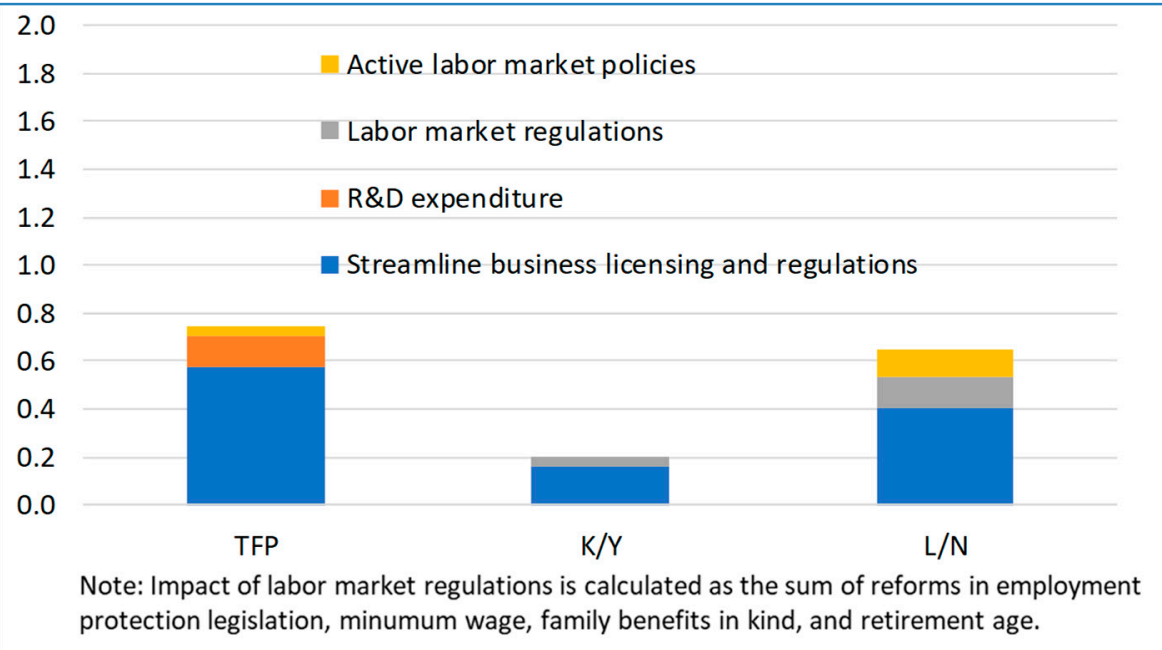

Source: IMF staff calculations based on Égert and Gal (2016, 2017) and OECD (2018).

Note: TFP refers to total factor productivity, $L$ and $K$ to employment and capital stock, respectively, $N$ to labor force, and $Y$ to output. 


\section{B. Reaching the OECD Median}

To reach the OECD median level, a substantially more ambitious and challenging set of reforms than the baseline is necessary. Figure 12 a provides a quantification of the impact of such structural reforms on Chile's output level: closing all structural gaps with respect to the current median of the OECD group is likely to result in substantially higher output level, estimated at over 10 percent after 5 years (and double this impact after full convergence). Such a set of reforms is estimated to result in direct fiscal costs of about $1 \frac{1}{2}$ percent of GDP, which is likely to be more than offset by more revenues due to higher output, resulting in a positive net fiscal effect of about 1 percent of GDP after 5 years (Figure 12b). As in the baseline scenario, TFP will be the factor of production experiencing the largest gains over this period. While this scenario results in substantially larger gains, it requires an unprecedented set of policies that substantially exceeds the international experience with structural reforms and may be politically and institutionally difficult to implement.

Figure 12a: Impact on Structural Reforms on GDP Level (Reach Median of OECD, in Percent)

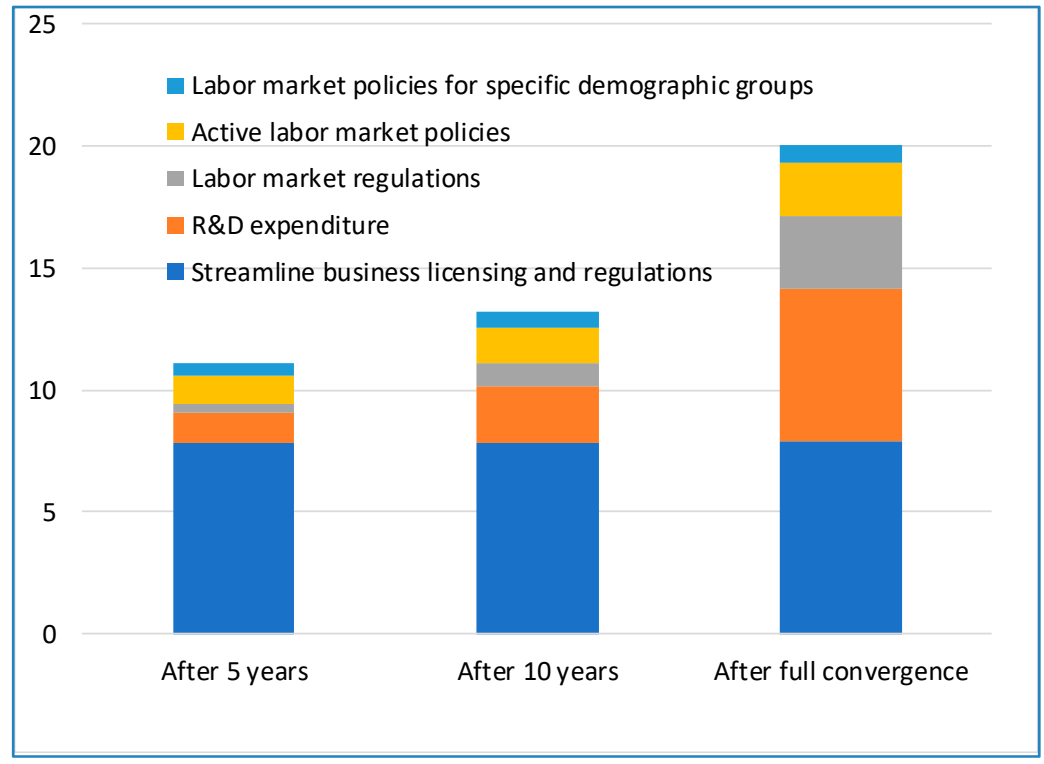

Source: IMF staff calculations based on Égert and Gal (2016, 2017) and OECD (2018). 
Figure 12b: Impact on Fiscal Balance

(Reach Median of OECD, in Percent of GDP)

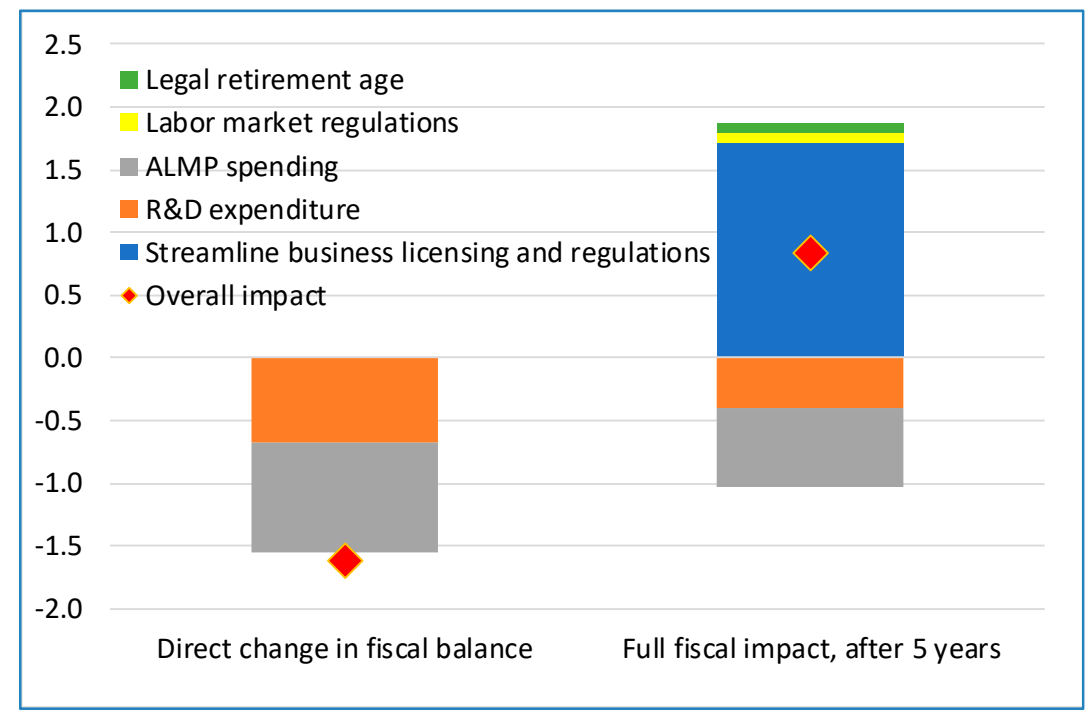

Source: IMF staff calculations based on OECD (2018).

Figure 12c: Impact on Factors of Production (TFP and $\mathrm{K} / \mathrm{L}$ in Percent, $\mathrm{L} / \mathrm{N}$ in Percentage Points)

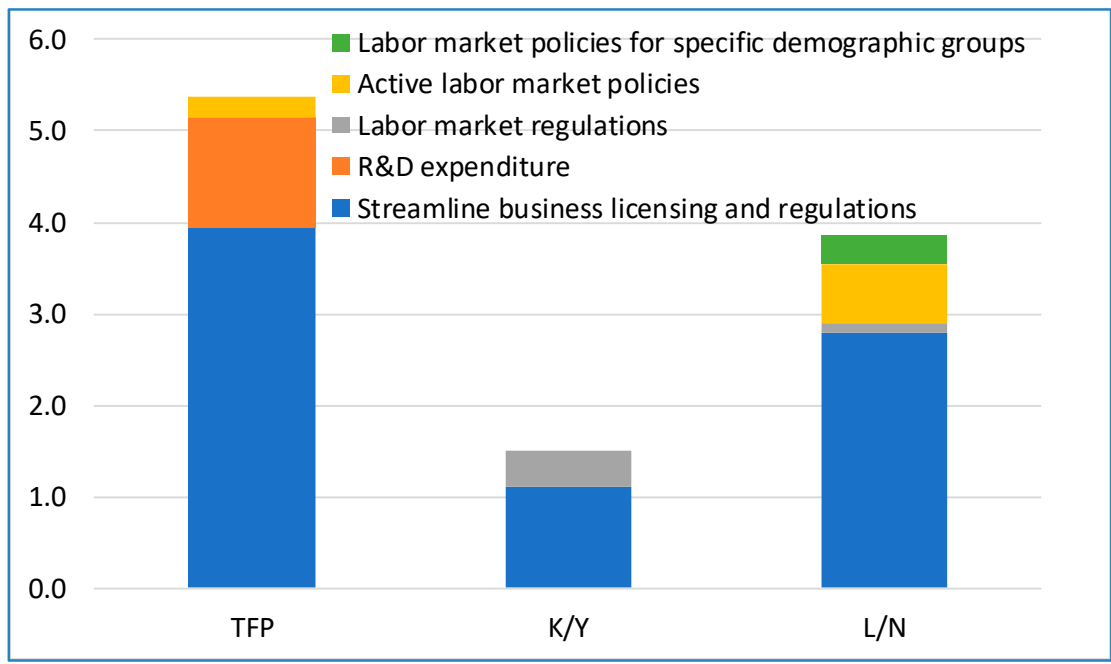

Source: IMF staff calculations based on Égert and Gal (2016, 2017) and OECD (2018). Note: TFP refers to total factor productivity, $L$ and $K$ to employment and capital stock, respectively, $N$ to labor force, and $Y$ to output. 


\section{REFORMS SYNCHRONICITY}

This section provides a quick analysis of reform synchronicity, based on the historical evidence about the extent to which reforms were jointly implemented, which can offer additional insights valuable in deciding how to practically implement the various reforms.

Degree of synchronicity differs across reforms. Traditionally, some structural reforms are more likely to be implemented jointly than other type of reforms. This may be either just due to inherent complementarity from the economic perspective or for political economy considerations. For instance, one the one hand, the combination of higher labor market flexibility (or less rigid labor protection legislation) may present synergies when implemented concurrently with enhanced active labor market policies, and thereby help reallocate labor to the most productive sectors. On the other hand, reforms in licensing procedures and product market deregulation may narrow the policy space to simultaneously implement substantial employment protection reforms. Similarly, it may be politically difficult to implement minimum wage reform together with significant changes in the pension system.

\section{Historical examples can offer a preliminary indication about possible reforms} synchronicity. Figure 13 shows the degree of synchronicity across different types of reforms that have been implemented over the period 1960-2013. Using the indicators from the SPIDER database, it presents correlations among structural reform actions implemented over five-year reform horizons. ${ }^{7}$ A positive (negative) value suggests that the combination of growth-enhancing reforms was more (less) commonly implemented simultaneously, in the past. Of course, this exercise does not assess causality, and the correlation in part may be spurious. Nonetheless, the correlations are calculated over 45 countries and more than 4 decades (unbalanced dataset), and thus may be indicative of patterns.

Combinations of reforms with the highest growth payoffs for Chile were not necessarily more likely to be implemented simultaneously in the international experience. For instance, licensing and regulatory reforms were more likely to coincide with active labor market policies, minimum wage and pension reforms, though less likely to come along with an increase in R\&D expenditure or employment protection reforms. On the other hand, employment protection reforms seem to have taken place simultaneously with increases in $\mathrm{R} \& \mathrm{D}$ expenditure and pension reforms.

Further analysis would be necessary to assess reform synchronicity and possible complementarity, and possibly exploit it via reform packages. It will be valuable to further assess complementarity from the theoretical perspective as well as via deeper

\footnotetext{
${ }^{7}$ Correlations included in the matrix are calculated on the basis of sign-adjusted structural indicators, so that positive changes in the indicators reflect a growth-enhancing reform, consistent with the other comparisons presented in this paper.
} 
evidence shedding light on the reasons behind these historical correlations of reforms. This would help the policymaker make informed decision about which reform are either more effective or more politically feasible when implemented together.

Figure 13: Synchronicity of Structural Reforms

\begin{tabular}{|c|c|c|c|c|c|c|c|c|}
\hline & $\begin{array}{l}\text { Licensing and } \\
\text { regulations }\end{array}$ & ETC Regulations & R\&D expenditure & \begin{tabular}{|l|} 
Employment \\
protection \\
legislation \\
\end{tabular} & $\begin{array}{l}\text { Active labor } \\
\text { market policies }\end{array}$ & Minimum wage & $\begin{array}{l}\text { Family benefits } \\
\text { in kind }\end{array}$ & $\begin{array}{l}\text { Legal retirement } \\
\text { age }\end{array}$ \\
\hline $\begin{array}{l}\text { Licensing and } \\
\text { regulations }\end{array}$ & & & & & & & & \\
\hline ETC Regulations & 0.01 & & & & & & & \\
\hline R\&D expenditure & -0.18 & -0.16 & & & & & & \\
\hline $\begin{array}{l}\text { Employment } \\
\text { protection legislation }\end{array}$ & -0.39 & -0.31 & 0.34 & & & & & \\
\hline $\begin{array}{l}\text { Active labor market } \\
\text { policies }\end{array}$ & 0.14 & -0.03 & 0.15 & -0.09 & & & & \\
\hline Minimum wage & 0.11 & -0.17 & -0.37 & 0.01 & -0.21 & & & \\
\hline $\begin{array}{l}\text { Family benefits in } \\
\text { kind }\end{array}$ & -0.11 & 0.12 & 0.14 & -0.18 & 0.15 & -0.33 & & \\
\hline Legal retirement age & 0.10 & 0.22 & -0.11 & 0.31 & -0.03 & -0.12 & 0.00 & \\
\hline
\end{tabular}

Note: Correlation matrix of structural reforms which are measured as the change in the structural indicators from the SPIDER database over 5-year reform horizons in the period 1960-2013.

\section{CONCLUDing REMARKS}

Chile's economy is likely to benefit from implementation of structural reforms that can raise productivity and output without adversely affecting the fiscal position. Primarily, a comprehensive streamlining of Chile's licensing and permit procedures, and better coordination among regulatory institutions is likely to result in significant growth dividends with minimal initial fiscal outlays. Therefore, product market reforms deserve a centerstage in Chile's priority reform arena. Such reforms are likely to improve the overall business environment and help growth through accumulation of production factors as well as higher productivity. In addition, higher labor market flexibility, enhanced and better-targeted active labor market policies, and strengthened capacity for innovation and R\&D are likely to play a positive role with limited fiscal costs. Overall, this study presented a scenario in which Chile closes the policy gap in these four key areas with OECD's $25^{\text {th }}$ percentile over five years. The possible benefits can be up to 6 percent higher output level and a cumulative net fiscal gain of about $1 / 2$ percent of GDP, although the output gains are likely to be backloaded. Combinations of reforms with the highest growth payoffs for Chile were not necessarily more likely to be implemented simultaneously in the international experience. Further analysis on reform synchronicity and possible complementarity may help design a roadmap about the feasibility of implementing alternative reform packages in the future. Alternative reform scenarios are also explored to provide a richer context for assessing the feasibility and the potential impact of reform packages. On the one hand, the scenario composed of the 
typically-observed reforms over a five-year period may not be seen as sufficiently ambitious. On the other hand, more ambitious reform scenarios, such as the one that closes the gaps with the median of the OECD, could provide even stronger boost to output, but are less likely to materialize over a four- or five-year policy reform horizon. 


\section{REFERENCES:}

Dudine, P. and J. T. Jalles (2017), "How Buoyant is the Tax System? New Evidence from a Large Heterogenous Panel", IMF Working Paper 17/4.

Duval, R., D. Furceri, B. Hu, J. Jalles, and H. Nguyen (2018), “A Narrative Database for Major Labor and Product Market Reforms in Advanced Economies", IMF Working Paper $18 / 19$.

Duval, R. and D. Furceri (2018), "The Effect of Labor and Product Market Reforms: The Role of Macroeconomic Conditions and Policies", IMF Economic Review, 66, pp. 31-69.

Égert, B. and P. Gal (2016), "The Quantification of Structural Reforms in OECD Countries: A New Framework", OECD Economics Department Working Papers No.1354.

Égert, B. and P. Gal (2017), "The Quantification of Structural Reforms in OECD Countries: A New Framework”, OECD Journal: Economic Studies, Vol. 2016/1.

Égert, B., P. Gal, and I. Wanner (2017), "Structural Policy Indicators Database for Economic Research (SPIDER)", OECD Economics Department Working Papers No. 1429.

IMF (2015), Structural Reforms and Macroeconomic Performance: Initial Considerations for the Fund.

IMF (2016), Staff Note for the G20-A Guiding Framework for Structural Reforms.

OECD (2017), Education in Chile, Reviews of National Policies for Education, OECD Publishing, Paris.

OECD (2018), OECD Economic Surveys: Chile 2018, OECD Publishing, Paris.

WEF (2017), Global Competitiveness Report 2017-2018.

World Bank (2017), Republic of Chile Systematic Country Diagnostic: Transitioning to a Prosperous Society, World Bank, Washington, DC. 